\title{
COEXISTENCE X VIOLENCE IN THE SCHOOL: A CONTEMPORARY CHALLENGE
}

\section{PRESENTATION}

In this section, the theme "ethical coexistence $\mathrm{X}$ violence" is approached from certain contingencies that, although not restricted to the school universe, find in it an important and valuable locus of manifestation.

Important because it is in the school the emotions arising from interpersonal relations spark students with sui generis intensity, focusing on the construction of their morality. Valuable, therefore, this condition gives opportunity to school, in that it raises the coexistence object to the systematic status of reflection, the development of intentional practices and known effectiveness directed to the formation of moral values we so desire.

For this, it is not possible to dispense, as the world literature has shown, a teacher training capable of subsidizing them so that they can work with the issue of coexistence as a value, thus freeing them from the ties that bind them in the face of the task of overcoming the problems of coexistence that are perpetuated in the insufficiency of moral values. It is essential to understand the dynamics of moral development and conflict resolution processes of children and adolescents in order to intervene.

Likewise, it is urgent to reflect on unusual forms of violence that overlap the walls of the school, such as cyberbullying and other forms of cyber-aggression, and again the ways in which modern society can meet the challenge of human formation just, generous, respectful - in the real and virtual world.

These are the crucial points highlighted in this section. 
Article 1: Bullying and cyberbullying: when moral values are lacking and coexistence is shaking.

Article 2: When virtual violence hits us: education programs to overcome cyberbullying and other virtual aggressions.

Article 3: Conflicts between 8- and 9-year-olds - provocation and reaction to disruptive behavior: what educators should know.

\author{
Luciene Regina Paulino TOGNETTA ${ }^{1}$ \\ Darlene Ferraz KNOENER ${ }^{2}$ \\ Sanderli Ap. Bicudo BOMFIM ${ }^{3}$ \\ Sandra Trambaiolli DE NADAI ${ }^{4}$ \\ Thais Cristina Leite BOZZA ${ }^{5}$ \\ Telma Pileggi VINHA ${ }^{6}$ \\ Lívia Maria Ferreira da SILVA ${ }^{7}$
}

${ }^{1}$ Universidade Estadual Paulista (Unesp), Araraquara - SP - Brasil. Professora do Departamento de Psicologia da Educação Pedagoga. Líder do GEPEM - UNESP/UNICAMP. E-mail: lrpaulino@uol.com.br

${ }^{2}$ Universidade Estadual Paulista (Unesp), Araraquara - SP - Brasil. Mestranda em Educação Escolar. Membro do GEPEM - UNESP/UNICAMP. E-mail: darlene.knoener@gmail.com

${ }^{3}$ Universidade Estadual Paulista (Unesp), Araraquara - SP - Brasil. Mestranda em Educação Escolar. Membro do GEPEM - UNESP/UNICAMP. E-mail: sanderli.bicudo@gmail.com

${ }^{4}$ Universidade Estadual Paulista (Unesp), Araraquara - SP - Brasil. Mestranda em Educação Escolar. Membro do GEPEM - UNESP/UNICAMP.. E-mail: sctnadai@ hotmail.com

${ }^{5}$ Universidade Estadual de Campinas (Unicamp), Campinas - SP - Brasil. Doutoranda em Educação na área de Psicologia. Membro do GEPEM - UNESP/UNICAMP. E-mail: thaisbozza@ hotmail.com

${ }^{6}$ Universidade Estadual de Campinas (Unicamp), Campinas - SP - Brasil. Professora do departamento de psicologia educacional da UNICAMP. Membro do Laboratório de Psicologia Genética da UNICAMP e líder do GEPEM - UNESP/UNICAMP. E-mail: telmavinha@uol.com.br

${ }^{7}$ Doutora em Educação pela Unicamp, com estágio sanduíche na Harvard Graduate School of Education. Membro do Laboratório de Psicologia Genética da UNICAMP e do GEPEM - UNESP/UNICAMP. Email: liviamfsilva@gmail.com 